\title{
Treatise on Sympathetic Response, [Spoken by] the Supreme
}

\author{
Tatiana I. Kornil'eva* \\ Saint Petersburg State University \\ 7/9 University Embankment Str. Petersburg, \\ 199034, Russia
}

Received 26.09.2017, received in revised form 04.12.2017, accepted 07.12.2017

This article describes one of the most popular and influential Chinese medieval religious texts - the "Treatise on Sympathetic Response, [spoken by] the Supreme" (太上感應篇). This text has been circulating among lay people since the Song dynasty and nowadays still remains one of the most frequently encountered shanshu texts. The paper covers such issues as structure, religious affiliation, authorship and influence of the Treatise. In addition, the article analyzes why and how this text became so popular. In modern China they use animation to attract the new audience.

Keywords: "Treatise on Sympathetic Response, [spoken by] the Supreme", shanshu, taoism, religious literature.

DOI: 10.17516/1997-1370-0189.

Research area: philology.

"Treatise on Sympathetic Response, [spoken by] the Supreme" (Tài shàng gănyìng piān, 太 上感應篇) is one of the most well-known and influential religious texts in China. It dates back to $12^{\text {th }}$ century (Sothern Song dynasty) and it is believed to be the first text of shanshu literature.

Shanshu (善書), or Quanshanshu (勸善 書), literary means “morality books" or "books of moral persuasion". Indeed these books are on religion subject aiming to provoke consciousness and virtue. Usually these texts are copied or printed by lay people on their own money for free distribution. Such acts are believed to help gaining merits and cleansing karma. In ordinary language the term "shanshu" comprises a vast stratum of religious literature. As a matter of fact any book, which is freely distributed in temples, is called shanshu. Nevertheless, one should accept that the core, or "classical" texts of shanshu literature, share common peculiarities and present specific kind of books. In order to distinguish these two meanings in this paper I suggest using "shanshu genre" term for the later meaning.

Traditionally "Treatise on Sympathetic Response..." is referred as one of the so-called “ThreeHoly Sutras”(Shànshūsānshèngjīng, 善書 三聖經), which include “Treatise on Sympathetic Response, [spoken by] the Supreme" (Tài shàng gănyìng piān, 太上感應片), “Lord Superior Wen Chang Tract of the Quiet Way" (Wénchāng

(C) Siberian Federal University. All rights reserved

* Corresponding author E-mail address: t.kornilyeva@yandex.ru 
dijūn yīnzhì wén, 文昌帝君院鴊文) and “Perfect Book of Emperor Guan's Enlightenment" (Guān shèngdì jūn jué shì zhēn jīng, 關聖帝君覺世「經). Some scholars call them "Classical texts of folk religion” (Mínjiān zōngjiào zhōng de jīngdiăn, 民 間宗「中的經典). They were first joined up and published under the same cover entitled "The Three Holy Scriptures" (Sān shèngjīng, 三聖經) in 1806 (Brokaw, 1991: 86).

In terms of literature the "Treatise..." belongs to a short length prosaic genre. In terms of subject it occupies a terminal place between religious and secular literature. Nowadays these texts, as well as most of the shanshu genre, are usually considered to belong to the taoist tradition. In fact they combine elements of all the Three teachings - Buddhism, Taoist and Confucianism - which make them a perfect example of folk religion texts.

The main part of the "Treatise..." consists of two pieces: the first one describes an example of a good man while the second one describes a bad man. All the good and the bad deeds are evaluated in a period of time (twelve years or one hundred days) that is added to or subtracted from the lifetime of a person. It is believed that in the Heaven they use exactly the same system, so this is how one can know beforehand what he can expect from his deeds in the future and even in afterlife.

The authorship of the "Treatise..." is obscure. According to professor Sakai Tadao it must have been compiled by the lower stratum scholars (xiàjí dúshūrén, 下級讀書人) (Treatise on Sympathetic Response..., 2006: 735). In the text itself it is said that it was transfered to people by the deified founder of Taoism Lao-zi - Taishang, or Taishang Laojun (太上老君), which means “Supreme Old Lord". Taishang is believed to be one of the Three Pure Ones (sān qīng, 三「) - the supreme deities in Taoism. In another words they borrowed authority of some powerful deities of the Chinese pantheon to create a more significant impact. Such measure became common pattern in books of the shanshu genre as they were supposed to be taken as a direct covenants of the gods, as a source of the supreme wisdom of the word order and the maxims, outlined in these texts, were to be perceived as dogmas.

The language of narration of the "Treatise..." contains numerous examples of words and phrases that are more typical for historical or philosophic writings, rather than religious. That proves the assumption that they were created by the literati representatives and thereby depicted their life values.

It is believed that the emperor of the Northern Song dynasty Song Zhen-zong (宋 「宗, r. 997-1022) granted one million silver ingots on publishing and distributing of the "Treatise..." (Wieger, 1913). Further more Cynthia Brokaw mentions that "in early Ming, the Hungwu emperor (r. 1368-1398) sponsored an extensive campaign on morality-book publication" (Stebulyanina, 2014: 62). These facts demonstrate us that the government of China understood the significance of such pieces of literature concerning to social conscience control. Indeed it was a great tool to convey ideas and to promulgate scale of values among the masses. Moreover it was (and apparently is) considered to be a great virtue to rewrite or reprint these texts, hence the system started to reproduce itself.

Later on, according to the "Treatise...", they compiled the ledgers of merit and demerit (Tài shàng gănyìng piān gōngguò gé, 太上感應篇功 過格). With the help of the ledgers one can easily evaluate his deeds in the matter of morality and know how to improve himself. The emergence of the "Treatise..." ledgers is a vivid evidence of popularity of the text.

In modern China up-to-date ways to attract the audience are in use. Many of the morality- 
books are published as cartoon books and turn into the plot for animated movies. The animated movie after the "Treatise..." called "Stories of the
Treatise on Sympathetic Response, [spoken by] the Supreme" was made in Taiwan and consists of 30 series.

\section{References}

Brokaw, C.J. (1991). The Ledgers of Merit and Demerit: Social Change and Moral Order in Late Imperial China. Princeton, New Jersey, Princeton University Press, 304 p.

Sakai Tadao. (2010). Zhongguo shanshu yanjiu [Studies on Chinese morality books] 酒井忠夫.中 國善書「究 (translation Sun Xuemei 孫雪梅) Vol. 1-2, Nanjing, Phoenix Publishing \& Media Group, $840 \mathrm{p}$.

Stebulyanina, E.M. (2014). Knigi ucheta zaslug i prostupkov "Traktat o bozhestvennom vozdayanii". [The Ledgers of Merit and Demerit [Treatise on Sympathetic Response, [spoken by] the Supreme], In Chelovek i kultura Vostoka: issledovaniya i perevody. [The Man and the Oriental Culture: researchers and translations 2012]. 170-180.

Storozhuk, A.G., Kornilyeva, T.I., Zavidovskaya, E.A. (2012). Dukhi i bozhestva kitajskoj preispodnej [Gods and Demons of the Chinese Hell], St. Petersburg, Karo, 464 p.

Treatise on Sympathetic Response, [spoken by] the Supreme (Taishang gaiying pian) 太上感應 篇, (2006). Beijing, Baiyunguan, 187 p.

Wieger, L. (1913). Moral Tenets and Customs in China. Peking, Catholic Mission Press, 604 p.

You Zian. (2012). Shanshu and chinese Religions: selected papers by You Zian (Shanshu yu zhongguo zongjiao: You Zian zixuanji) 遊子安. 善書與 中國宗「:遊子安自選集. Taiwan, Taipei, Boyang wenhua, $382 \mathrm{p}$.

\section{Книга откровений Тайшана}

Т.И. Корнильева

Санкт-Петербургский государственный университет Россия, 199034, Санкт-Петербург, Университетская набережная, 7/9

В данной статье рассматривается один из самых популярных и влиятельных религиозных текстов средневекового Китая - «Книга откровений Тайшана» (太上感應篇). Этот текст имел хождение среди мирян начиная с династии Сун и в настоящее время остается одним из самых часто встречающихся текстов шаньшу. В статье освещаются такие аспекты, как структура, религиозная принадлежность, авторство и влияние «Книги откровений...». Кроме того, анализируется, почему и как этот текст стал настолько популярным. В современном Китае для привлечения новой аудитории к «Книге откровений...» обращаются к мультипликации.

Ключевые слова: «Книга откровений Тайшана», ианьшу, даосизм, религиозная литература.

Научная спеииальность: 10.00.00 - филологические науки. 